\begin{tabular}{lcr}
\hline & ANNALES \\
& UNIVERSITATIS MARIAE CURIE-SKŁODOWSKA & \\
LOL. I & LUBLIN - POLONIA & 2016 \\
\hline
\end{tabular}

Elżbieta Kużelewska

University of Bialystok

\title{
Do the Poles Influence the Decision-Making Process by Applying Direct Democracy Instruments?*
}

\section{Introduction}

The modern concept of democracy is based on the idea of popular sovereignty. Sovereignty means that the actions of the state must be legitimated by the people. The people is sovereign and in this context, to exercise the state power it represents the supreme basis of legitimation ${ }^{1}$. Citizen participation in decision-making is a founding principle of democracy. Direct democracy provides opportunities for citizens to directly influence the laws of their community and implement their policy preferences ${ }^{2}$.

The phenomenon of direct democracy is significant in particular in Switzerland and California, not in Poland. Indeed, direct democracy, in particular referendum and popular initiative, is becoming a bit more significant in Polish political life. Nevertheless, it has not replaced representative democracy but it has complemented it. Before 1989, only two referenda were held in Poland, in 1946 and in

* This article is the result of research project No. 2014/15/B/HS5/01866 funded by the National Science Centre.

1 W. Marxer, Z.T. Pállinger, System context and system effects of direct democracy - direct democracy in Liechtenstein and Switzerland compared, [in:] Direct Democracy in Europe. Developments and Prospects, eds. Z.T. Pállinger, B. Kaufmann, W. Marxer, T. Schiller, Springer, Wiesbaden 2007, p. 14.

2 S. Reilly, Design, Meaning and Choice in Direct Democracy. The Influences of Petitioners and Voters, Ashgate Publishing Limited, Ashgate 2010, p. 3. 
1987. In the former referendum, communist authorities organized it to consolidate the system imposed by the Soviet Union. The latter was to obtain support for difficult economic and political reforms implemented by communist authorities.

In this paper the author will focus on the notion of referendum and popular initiative, which seems to be the most common form of direct democracy exercised in Poland.

The aim of this paper is to analyze the role of direct democracy's forms in decision-making process in Poland. The paper focuses on three issues. Firstly, the use of referendum and its frequency. Secondly, which problems were to be solved in the referendum. Thirdly, what are the matters that are related to the projects submitted under the popular initiative.

This paper is divided into six parts. Section 1 starts with a brief general analysis of the constitutional background of referendum and its procedures. Section 2 describes the referendum experience, subjects of the vote, initiators of the vote and referenda results. Referendum on EU membership is analyzed in section 3. In section 4 the citizens' initiative and popular initiative are discussed. In section 5 unsuccessful proposals to hold a referendum are considered. Finally, section 6 will draw some conclusions.

\section{Constitutional bases of referendum in Poland}

The constitution of Poland does not mention the issues excluded from national referendum. According to Art. 125., a referendum can be held in cases important for the state. However, competence belonging to the state authority cannot be the subject of referendum. Legislative referendum is also forbidden ${ }^{3}$.

Thirdly, the constitution of Poland (Art. 125(3)) describes the situations when a referendum is binding. The Supreme Court decides upon the validity of a referendum.

The constitution of the Republic of Poland distinguishes three types of referenda: (1) a referendum at the national level, (2) a constitutional referendum for amendments in the constitution, and (3) a local referendum. Referendum at the national level is provided in Art. 125 of the constitution and a referendum at the national level can be held in cases important for the state. The national referendum is optional. The decision about referendum depends on authorities: the Sejm (lower chamber) or the president with the Senate's approval. A national

3 K. Prokop, Institutions of Direct Democracy in the Republic of Poland, [in:] Proceedings of the 52nd International Scientific Conference of Daugavpils University, ed. I. Zugicka, University of Daugavpils, Daugavpils 2011, p. 1319. 
referendum can be held only in solemn matters ${ }^{4}$. The subject of referendum is mentioned in Art. 90(3): agreeing to transfer the competences of national authorities in certain matters to an international organization or organ.

The concept of referendum in Poland is subject to a detailed regulation by the acts of Parliament. Art 63(1) of the Referendum Act of March 14 ${ }^{\text {th }} 2003^{5}$ concerns the referendum at national level. It specifies that the Parliament can submit certain cases to be a referendum being that it is the initiative of citizens who receive support for their motion of at least 100,000 citizens eligible for participation in a referendum. However, it does not change the fact that MPs have their decisive vote. Referenda resulting from citizens' initiative cannot concern expenditures and revenues, state defense and amnesty.

Art. 170 of the constitution refers to local referendum. Art 235(6) concerns the referendum for amendments to the constitution. The speaker of the Sejm ordains this referendum within 60 days after submitting the motion by at least one-fifth of the members of the Sejm, the senate, or the president of the Republic of Poland.

In order to regard its results as binding, in the case of referenda at the national level concerning issues particularly important to the state and concerning accepting ratification of international agreement, it is required that more than $50 \%$ of citizens eligible to vote take part in it. This requirement does not apply in the case of referenda authorizing the change of the constitution. Art. 79 of the Referendum Act states that changing the Constitution by referendum goes into affect only if the majority of voters approve it.

Table 1

Referenda compulsory and non-compulsory (optional) in Poland

\begin{tabular}{|l|l|}
\hline Country & Poland \\
\hline $\begin{array}{l}\text { Compulsory } \\
\text { referendum }\end{array}$ & No \\
\hline $\begin{array}{l}\text { Non-compulsory } \\
\text { referendum }\end{array}$ & $\begin{array}{l}\text { Constitutional referendum (Art 245) in the case of the amendment to the } \\
\text { Issue referendum (Art. 125) - on the solemn matters. } \\
\text { Accession referendum (Art. 90(3)) - concerning the consent for the ratifica- } \\
\text { tion of the international agreements, on the basis of which Poland passes } \\
\text { part of the state organ competences to an international organization. }\end{array}$ \\
\hline
\end{tabular}

Source: A. Rytel-Warzocha, Referendum ogólnokrajowe w państwach Europy Środkowo-Wschodniej, Wydawnictwo Sejmowe, Warszawa 2011, p. 131-132.

4 E. Zieliński, Referendum w Polsce, [in:] Referendum w państwach Europy, eds. E. Zieliński, I. Bokszczanin, J. Zieliński, Fundacja Europea, Oficyna Wydawnicza Aspra, Warszawa 2003, p. 228.

5 Referendum Act of 14 March 2003, http://isap.sejm.gov.pl (Dz. U. z 2003 r. Nr 57, poz. 507, Nr 85, poz. 782, z 2007 r. Nr 112, poz. 766, z 2009 r. Nr 68, poz. 573, Nr 202, poz. 1547, z 2011 r. Nr 21, poz. 113, Nr 106, poz. 622, Nr 147, poz. 881 ). 
Table 2

Referendum framework in Poland

\begin{tabular}{|l|l|}
\hline Referendum & Poland \\
\hline Who calls it? & $\begin{array}{l}\text { The Sejm (the lower chamber of Parliament) or The President with accept- } \\
\text { ance of The Senate (the higher chamber of Parliament) }\end{array}$ \\
\hline $\begin{array}{l}\text { When referendum } \\
\text { cannot be held? }\end{array}$ & - \\
\hline Validity/binding & $\begin{array}{l}\text { Referendum is binding if more than half of all electors have voted; the valid- } \\
\text { ity of the referendum is pronounced by the Supreme Court. }\end{array}$ \\
\hline
\end{tabular}

Source: self-made.

The validity/binding of a referendum depends on the people's participation in it (turnout). Both, the president of Poland and the lower chamber of the parliament are entitled to hold a referendum.

\section{The referendum experience in Poland}

Since World War II, there were six referenda held in Poland. The 1946 referendum aimed at gaining power for the communists and the results were falsified. In 1987, citizens voted on political and economic reforms.

Table 3

Referenda in Poland

\begin{tabular}{|c|c|c|c|c|c|}
\hline Date of vote & Subject of referendum & $\begin{array}{l}\text { Turnout } \\
\%\end{array}$ & $\begin{array}{c}\text { For } \\
\%\end{array}$ & $\begin{array}{l}\text { Against } \\
\%\end{array}$ & Result \\
\hline \multirow{3}{*}{30 June 1946} & Economic reform & 90.10 & 77.15 & 22.85 & Yes \\
\hline & Abolition of the Senate & 90.10 & 68.03 & 31.97 & Yes \\
\hline & $\begin{array}{l}\text { Borders with a Germany and the Baltic } \\
\text { States (Oder/Neisse) }\end{array}$ & 90.10 & 91.36 & 8.64 & Yes \\
\hline \multirow{2}{*}{$\begin{array}{l}29 \text { November } \\
1987\end{array}$} & Political reform & 67.05 & 46.29 & 15.79 & No \\
\hline & Economic reform & 90.10 & 77.15 & 22.85 & No \\
\hline \multirow{5}{*}{$\begin{array}{l}18 \text { February } \\
1996\end{array}$} & Privatisation programme & 32.40 & 96.15 & 3.85 & No \\
\hline & $\begin{array}{l}\text { Investing profit generated by privatization } \\
\text { into the public pension found }\end{array}$ & \multirow{4}{*}{32.44} & 95.99 & 4.01 & No \\
\hline & Privatisation using coupons & & 91.32 & 8.68 & No \\
\hline & $\begin{array}{l}\text { Extension of mass privatisation by the } \mathrm{Na}- \\
\text { tional Investment Found }\end{array}$ & & 23.16 & 76.84 & No \\
\hline & $\begin{array}{l}\text { Financing pension payment with profit } \\
\text { greeted by privatization }\end{array}$ & & 95.07 & 4.93 & No \\
\hline 25 May 1997 & Constitution & 42.86 & 53.45 & 46.55 & Yes \\
\hline
\end{tabular}




\begin{tabular}{|l|l|c|c|c|c|}
\hline \multirow{2}{*}{ Date of vote } & \multicolumn{1}{|c|}{ Subject of referendum } & $\begin{array}{c}\text { Turnout } \\
\%\end{array}$ & $\begin{array}{c}\text { For } \\
\%\end{array}$ & $\begin{array}{c}\text { Against } \\
\%\end{array}$ & Result \\
\hline 8 June 2003 & Accession to the EU & 58.85 & 77.45 & 22.55 & Yes \\
\hline \multirow{3}{*}{$\begin{array}{l}\text { 6 September } \\
2015\end{array}$} & $\begin{array}{l}\text { Introduction of single-seat constituencies } \\
\text { in elections for the Sejm }\end{array}$ & & 78.75 & 21.25 & No \\
\cline { 2 - 2 } \cline { 5 - 6 } & $\begin{array}{l}\text { Support current method of financing of } \\
\text { political parties from the state budget }\end{array}$ & 7.80 & 17.37 & 82.63 & No \\
\cline { 2 - 2 } \cline { 5 - 7 } & $\begin{array}{l}\text { Introduction of general principle of resolv- } \\
\text { ing doubts about the interpretation of tax } \\
\text { law for the benefit of the taxpayer }\end{array}$ & & 94.51 & 5.41 & No \\
\hline
\end{tabular}

Source: Państwowa Komisja Wyborcza, http://referendum2015.pkw.gov.pl, access: 15 VI 2016.

Since 1989 there have been only four referenda at the national level in Poland. The 1996 referendum was unsuccessful due to a low turnout. It was the president Lech Wałęsa's initiative to put forward a motion of referendum to the Senate with a question: "Do you support granting property rights to citizens"? The MPs added four further questions (see Table 6). In 1996, two referenda concerning the issue of granting property rights to citizens were performed within one course ${ }^{6}$. The low attendance partly reflected voters' opinions and the lack of knowledge about the referendum's subject. The majority of politicians were critical about the difficult to understand subject of the election ${ }^{7}$. Moreover, that referendum can be perceived as a kind of background to the fight for the presidency.

The 1997 referendum on the constitution was seen as a barometer for the September parliamentary election. According to Gebethner's opinion, the referendum was treated as a plebiscite of the political parties' popularity ${ }^{8}$. The political scene was clearly divided into the supporters and opponents of the new constitution'. Political parties supporting or rejecting the new constitution project did so willing to attract the biggest number of voters rather than showing their real opinion concerning the constitution. As Król writes, the constitution was a subject of a political conflict focused more on the legitimacy

6 A.K. Piasecki, Demokracja bezpośrednia w Polsce po 1989 roku, "Przegląd Sejmowy", 2006, no. 1(72), p. 14.

7 E. Kużelewska, A.R. Bartnicki, Referendum in Poland and Russia. Comparative analysis attempt, "The International Affairs Review", 2008, no. 1, 2 (157, 158), p. 122.

8 S. Gebethner, Poland, [in:] Direct Democracy. The Eastern and Central European Experience, eds. A. Auer, M. Bützer, Ashgate Publishing House, Aldershot, Burlington USA, Singapore-Sydney 2001, p. 135.

9 M. Marczewska-Rytko, Direct democracy at the national level in Poland. The case of referendum, "Annales Universitatis Mariae Curie-Skłodowska", 2013, Sectio K, vol. XX, 1, p. 111. 
of its adoption than on its actual wording and substance ${ }^{10}$. The disappointingly low turnout (43\%) in the constitutional referendum contrasts with declarations of the importance of the constitution in the lives of the Poles. Many of them declared that the constitution has a crucial influence on their lives despite having only a limited knowledge about its content ${ }^{11}$.

Penultimate referendum (2003) concerned Polish entry to the EU and was quite different from the previous ones due to many reasons. For the first time in Polish history, the referendum lasted two days. For the first time the Poles decided about such a solemn matter as an accession into the international organization. There was no referendum on NATO. The turnout in referendum (nearly 60\%) compared to previous referenda, can be called record-breaking. The success of the EU referendum was based also on other factors. First, the president, government, NGOs and mass media persuaded citizens to participate in the referendum. Second, there was a possibility of voting for two days. And third, the partial turnout was shown on Saturday, the first day of voting, and consequently mobilized the rest of the nation to take part.

The most recent one (2015) was the most unsuccessful for several reasons. Firstly, it was called by the President who lost the elections. Secondly, one of the questions was unconstitutional. Thirdly, the turnout was extremely low - less than $8 \%$. Referendum was held by the President Komorowski just a day after the I turn of presidential elections (where he came in the second place). Thus, he decided to hold a national referendum in order to increase his chances to win the presidential elections. Justifying his initiative, Komorowski explained the he followed the signal that the citizens wanted changes. However, it was clear that the referendum was a part of the presidential campaign. It also was recognized as an opportunism and the abuse of presidential position for campaign purposes. The eligible voters were asked to answer three questions: 1 / Are you for the introduction of single-seat constituencies in elections for the Polish Sejm?; 2/ Are you in favour of maintaining the current method of financing of political parties from the state budget?; 3/ Are you in favour of introducing a general principle of resolving doubts about the interpretation of tax law for the benefit of the taxpayer? All three questions raised a problem in relations to an unconstitutional nature of the first question, lack of precision of the second one, and finally irrelevance of the third ${ }^{12}$.

10 M. Król, Democracy in Poland, [in:] Democratization in Central and Eastern Europe, eds. M. Kaldor, I. Vejvoda, Pinter, London-New York 1999, p. 77.

11 B. Puchalska, Limits to Democratic Constitutionalism in Central and Eastern Europe, Routledge, Farnham 2011, p. 84.

12 M. Hartliński, The 2015 Referendum in Poland, "East European Quarterly", 2015, vol. 43, no. $2-3$, p. 237. 
The first question regarding single-seat constituencies was the main pretext to initiate the referendum. It should be underlined that such constituencies have been a rule since 2011 for the elections to the Senate, and since 2014 in elections to the commune councils in communes which are not district towns. Nonetheless, the Constitution does not permit to introduce the proposed solution (Article 96, p. 2). According to the quoted article, the elections to the Sejm are universal, equal, direct, proportional and conducted by secret ballot. The second question was rather general and did not suggest any precise solution. Therefore, it was difficult to determine the range of changes that would have to be implemented as a result of the citizens voting 'for' ${ }^{13}$. The aim of the second question was to publicly discuss the idea of abolishing the financing of political parties from the state budget. However, the answers 'yes' would suggest only the people's will to change the financing sources, without indicating the type of this change. The third question concerned the relationship between the taxpayers and the state. It was supposed to initiate changes in resolving any doubts about the interpretation of tax law for the benefit of the taxpayer, not the state's institutions. Nevertheless, on July 10, 2015, the Sejm passed an amendment of the tax statute which granted such a solution. In other words, this question was unfounded. Low turnout (less than $8 \%$ meant that the results of referendum were not binding. The referendum 2015 was a clear failure of the very idea of direct democracy in Poland, with the lowest turnout ever not only in Poland, but also in Europe after 1945.

\section{Referendum on the EU Membership}

As the question of the EU membership is a crucial one from a constitutional standpoint, let us compare the referenda on the EU accession held in 2003 in all analyzed countries. As de Waele observed, the governments in Central Europe seem to have felt that this "back to Europe" move had to be ratified by "democratic motivation". Political parties and elected representatives often seem too discredited and distant from the cares of the people to take responsibility for such a heavy, thoroughgoing move regarding the future of the country ${ }^{14}$.

The time of referendum on the EU membership was carefully tailored according to the domino-strategy adopted in the 1990s when referendums on EU membership took place in Austria, Finland, Sweden and Norway ${ }^{15}$. Domino-strategy

13 Ibidem, p. 238.

14 J.-M. de Waele, From membership referendums to European elections, [in:] European Union accession referendums, ed. J.-M. de Waele, Editions de l'Université de Bruxelles, Brussels 2005, p. 9.

15 D. Jahn, A.S. Storsved, Legitimacy through Referendum? The Nearly Successful Domino- 
was nearly successful, except for Norway ${ }^{16}$. According to the domino-strategy, the time of a referendum must be coordinated. The sequence of referenda depended on the support declared for the EU in particular countries ${ }^{17}$. It was believed that enthusiasm for European integration, which had already been expressed by successful referenda in some European countries, would be spread among other voters. In 2003 the domino-strategy proved to be successful. As Tucker rightfully predicted, the winners (countries of Eastern and Central Europe) who have done well by the transition were likely to support EU membership as it ensured a continuation of the transition process from which they have benefited ${ }^{18}$.

Table 4

Referenda on the EU membership in Central Europe

\begin{tabular}{|l|l|c|c|c|c|}
\hline \multicolumn{1}{|c|}{ Date of vote } & \multicolumn{1}{c|}{ Country } & Turnout \% & For \% & Against \% & Result \\
\hline 12 April 2003 & Hungary & 45.59 & 83.76 & 16.24 & Yes \\
\hline 16-17 May 2003 & Slovakia & 52.12 & 93.71 & 6.29 & Yes \\
\hline 13-14 June 2003 & Czech Republic & 55.18 & 77.33 & 22.67 & Yes \\
\hline 7-8 June 2003 & Poland & 58.85 & 77.45 & 22.55 & Yes \\
\hline
\end{tabular}

Source: Centre for Research on Direct Democracy 2003.

As the authorities of Slovakia, the Czech Republic and Poland were afraid of low participation (below 50\%), which could result in the invalidity of the referendum. So, they organized referenda lasting two days. This was a correct assumption. Moreover, according to the changes introduced into Polish law publishing the turnout data after the first day of a popular vote was allowed ${ }^{19}$. In Slovakia, the Czech Republic and Poland turnout was more than 50\% (the highest in Poland). A one-day referendum was only held in Hungary, as only $25 \%$ of participation was required for validity.

-Strategy of the EU-Referendums in Austria, Finland, Sweden and Norway, "West European Politics", 1995, vol. 18, no. 4, p. 21.

16 P.A. Pettersen, A.T. Jenssen, O. Listhaug, The 1994 Referendum in Norway: Continuity and Change, "Scandinavian Political Studies", 1996, vol. 19, no. 3, p. 265.

17 The sequence of holding referendum was the following: Malta (9 March 2003), Slovenia (23 March 2003), Hungary (12 April 2003), Lithuania (10-11 May 2003), Slovakia (16-17 May 2003), Poland (7-8 June 2003), the Czech Republic (13-14 June 2003), Estonia (14 September 2003), and Latvia (20 September 2003).

18 J.A. Tucker, A.C. Pacek, A.J. Berinsky, Transitional Winners and Losers: Attitudes towards EU Membership in Post-Communist Countries, "American Journal of Political Science", 2002, vol. 46, no. 3, p. 559.

19 J. Kilias, Symbole narodowe i problemy narodowościowe w polityce polskiej, [in:] Demokracja polska 1989-2003, eds. J.J. Wiatr, J. Raciborski, J. Bartkowski, B. Frątczak-Rudnicka, J. Kilias, Wydawnictwo Naukowe Scholar, Warszawa 2003, p. 314. 
The Poles voted as the last ones in the region. The outcomes of referenda in other Central European candidate countries might have also influenced the Polish standpoint and, in consequence, the positive result of referendum. Membership in the EU (and in NATO) was seen by the Polish government as a realization of national independence and continuation of the changes initiated in $1989^{20}$. During the last weeks before the referendum, more and more Poles were interested in participation in EU-referendum. In May 2003, 79\% of the respondents declared to cast their ballots, $64 \%$ of them had assured they would vote. Eventually, the turnout was $58.85 \%$ and it was lower than the people had declared. The Poles confirmed again that the real turnout was quite different from what had been declared ${ }^{21}$.

The EU accession referendum finished with double success of the EU supporters. Over three quarters of voters supported the accession. Over a half of the citizens took part in the referendum (which made it binding). The EU referendum carried lots of political weight. It forejudged whether Poland would become a member of the European Union or if it would be isolated from the new European order. Referendum as a form of direct democracy has started to play a more important role in political life.

Polish membership in the EU is, beyond any doubt, very important. Polish politicians decided to pose a question about the EU and let the nation answer ${ }^{2}{ }^{22}$. Citizens themselves were to decide about Poland's place in Europe, however, according to the Polish constitution, the Treaty of Accession could have been ratified by Polish parliament, without citizens' opinion.

The referendum result indisputably shows the success of the "Yes" side. However, supporters were not able to persuade hesitating people to support the EU. Eventually indecisive people (11\%) voted against membership. People complained against the lack of a solid campaign presenting advantages and disadvantages of the EU membership. The campaign for the EU was too sweet. On the other hand, the campaign against the EU was too propagandistic but

$20 \quad$ Ibidem, p. 313.

21 Previous referendums also indicated the different real turnout from declared. In referendum on privatization from $1996,52 \%$ of the respondents wanted to vote but finally $32 \%$ of the voters took a part in it. In constitutional referendum from 1997, 65-67\% of people declared their participation but $42.9 \%$ of the voters went to the ballot-boxes (A. Szymański, Frekwencja w polskim referendum akcesyjnym, [in:] Wymiar społeczny członkostwa Polski w Unii Europejskiej, eds. T. Mołdawa, K.A. Wojtaszczyk, A. Szymański, Warszawa 2003, p. 340).

22 J. Jaskiernia poses a question abort the rightiousness of using the referendum in Poland in the decision making process of our membership in the UE, J. Jaskiernia, Ustrojowe dylematy referendum akcesyjnego w Polsce, [in:] Wymiar społeczny członkostwa Polski w Unii Europejskiej, eds. T. Mołdawa, K.A. Wojtaszczyk, A. Szymański, Fundacja „Politeja”, Warszawa 2003, p. 320. 
the anti-campaign managed to convince the indecisive. It should be stressed here that the campaign was shadowed by the events from the Polish political scene. The so-called Rywingate was more interesting than arguments for Polish membership ${ }^{23}$. What was more was that a weak support for the Polish government and little confidence in politicians influenced the turnout.

The scale of support was different. It depended both on the age (Table 6) and the place of living (Table 8). All age groups supported Poland's entry to the EU, although the level of support was varied. There was a small difference between women and men in support of membership (Table 5). However, both genders were strongly in favor of the EU.

Table 5

Support for EU according to gender

\begin{tabular}{|l|c|c|}
\hline \multicolumn{1}{|c|}{ Gender } & Votes for "yes" & Votes for "no" \\
\hline Women & $85.1 \%$ & $14.9 \%$ \\
\hline Men & $83.8 \%$ & $16.2 \%$ \\
\hline
\end{tabular}

Source: Pracownia Badań Społecznych (PBS) in Sopot for the Polish Television, http://pbs.pl, access: 15 VI 2016.

Table 6

Support for EU according to age

\begin{tabular}{|l|c|c|}
\hline \multicolumn{1}{|c|}{ Age } & Votes for "yes" & Votes for "no" \\
\hline $18-24$ & $82.9 \%$ & $17.1 \%$ \\
\hline $25-39$ & $84.0 \%$ & $16.0 \%$ \\
\hline $40-59$ & $85.4 \%$ & $14.6 \%$ \\
\hline 60 and more & $84.7 \%$ & $15.3 \%$ \\
\hline
\end{tabular}

Source: PBS in Sopot for the Polish Television, http://pbs.pl, access: 15 VI 2016.

The result of referendum presents a surprising truth. The younger the voters were, the weaker the support for the EU was. Danuta Hübner, at that time the Polish minister for the EU issues, made some comments concerning young people's behaviour. She said: "Maybe this is a common youthful protest against things the adults propose. This phenomenon is inconceivable for me, I am astonished" ${ }^{24}$. Probably young voters were against membership because they wanted to manifest their protest against the Polish government. This is

23 I. Solecka, Obywatele przerośli polityków, "Rzeczpospolita”, 10 VI 2003, http://archiwum. rp.pl, access: 6 IX 2016.

24 “Gazeta Wyborcza”, 10 VI 2003, http://www.archiwum.wyborcza.pl, access: 6 IX 2016. 
one of the possible reasons. Another is that they wanted to protest against extended bureaucracy of the EU. We should also remember about youthful ideals and the craze for the anti-globalism style (EU can be an example of globalism $)^{25}$.

People between the age of 25 and 39 voted against the EU more often than other age groups. Middle-aged people (40-59) were the strongest "Yes" group. They are usually the most politically and professionally active group. Being at the top at the professional ladder, they voted along with the indicators of political elites. Apart from the middle-aged group, there was a group of older people who were in favor of the EU. Enthusiasm of retired people can be viewed as surprising, but we should remember the reasons why they voted for the EU. Elderly people voted for EU accession because of their belief in a better future for their grandchildren and great-grandchildren. What is more, their decision was reinforced by the Pope's words. John Paul II stressed that "Poland needs the European Union and the European Union needs Poland as well". ${ }^{26}$ The Pope and the Church's attitude towards integration had a strong influence on Polish approach towards EU.

Table 7

Support for EU according to education

\begin{tabular}{|l|c|c|}
\hline \multicolumn{1}{|c|}{ Education } & Votes for "yes" & Votes for "no" \\
\hline Primary & $74.6 \%$ & $25.4 \%$ \\
\hline Vocational & $77.7 \%$ & $22.3 \%$ \\
\hline College & $83.3 \%$ & $16.7 \%$ \\
\hline University & $88.0 \%$ & $12.0 \%$ \\
\hline
\end{tabular}

Source: PBS in Sopot for the Polish Television, http://pbs.pl, access: 6 VI 2016.

The better the education, the stronger the support for the EU. While the well-educated people were in favor for entry to the EU, the primary school graduates were the most anti-EU group. Their knowledge of the EU was not satisfactory so they were afraid of the consequences of Polish membership in the EU for themselves.

25 During one of the anarchists' demonstrations young people said: "The politics of the European Union is based on creation of a new iron curtain. It will divide the world into better and worse, poor and rich. What is more, a new iron curtain will isolate us from the East", "Gazeta Wyborcza”, 10 VI 2003, http://www.archiwum.wyborcza.pl, access: 7 IX 2016.

26 Ch. Châtelot, La Pologne, le plus grand des pays candidats, dit „oui” à l'Europe, “Le Monde", 10 iunie 2003, anul. 59, nr. 18154, p. 2. 
Table 8

Support for EU according to place of living

\begin{tabular}{|l|c|c|}
\hline \multicolumn{1}{|c|}{ Place of living } & Votes for "yes" & Votes for "no" \\
\hline Cities above 200 thousand & $88.9 \%$ & $11.1 \%$ \\
\hline Cities 50-200 thousand & $88.8 \%$ & $11.2 \%$ \\
\hline Towns up to 50 thousand & $86.6 \%$ & $13.4 \%$ \\
\hline Villages & $76.1 \%$ & $23.9 \%$ \\
\hline
\end{tabular}

Source: PBS in Sopot for the Polish Television, http://pbs.pl, access: 7 XI 2016.

The referendum also showed geographical cleavages. The surveys indicate the support for the EU independently with the place of residence. The supporters persuaded people who were hesitating before the referendum and, consequently, they voted for membership. However, there are some differences concerning support.

The EU-supporters were successful beyond any doubt in the whole country. Their biggest success was accomplished in cities and western regions. The bigger the cities, the higher support for the membership. People living in cities were the eagerest supporters of the EU. One fourth of those living in villages voted against.

\section{Citizens' initiative versus popular initiative on holding a national referendum}

There are two types of initiative in Poland: citizens' initiative and popular initiative, considering holding a national referendum. The former one is a constitutional institution whereas the latter is a statutory institution. The Constitution of the Republic of Poland adopted in 1997 introduced the institution of citizens' legislative initiative. Article 118 bill 2 states: "The right to introduce legislation shall also belong to a group of at least 100,000 citizens having the right to vote in elections to the Sejm. The procedure in such matter shall be specified by statute." Thus, the citizens' initiative is a form of direct democracy that entitles the group of citizens to submit a project of a normative act or a postulate to pass it, to a representative body ${ }^{27}$. Introducing the citizens' initiative to Polish legal system surely was a major step in civil society development. However, Eckhardt rightly points that the details concerning this institution had not been prepared in detail ${ }^{28}$. Firstly, the possibility to accept the citizens' projects, rejected by the

27 M. Jabłoński, Obywatelskie prawo inicjatywy ustawodawczej, [in:] Prawa $i$ wolności obywatelskie w Konstytucji RP, eds. B. Banaszak, A. Preisner, Wydawnictwo C.H. Beck, Warszawa 2002, pp. 645-646.

28 K. Eckhardt, Instytucja obywatelskiej inicjatywy ustawodawczej w Rzeczypospolitej 
Parliament, through a referendum was not considered, since the Constitution does not stipulate the referendum act. Secondly, the possibility to initiate the change of the Constitution by a citizens' legislative initiative was not provided. Thirdly, the committees of citizens' legislative initiative were left with no support during the stage of preparing the bill and its justification, and obviously the initiatives with no institutional support are fated to failure. Finally, the Parliament's obligation to take a clear standpoint concerning citizens' bill was not introduced, which with excluding the discontinuity principle is the reason why the parliamentary work is extremely long.

Popular initiative concerning the popular vote was introduced by the Polish National Referendum Act of 29th June 1995. The prior legislative regulations did not anticipate the situation when the group of citizens supported by least 100,000 citizens having the right to vote in elections to the Sejm comes up with a legislative proposal to organize a national referendum concerning the matters being of a great importance to the state. However, coming up with a legislative proposal is not equivalent to announcing the referendum. Popular initiative, despite the obligation to gain the support of a large group of people, is then examined by the Parliament. It means that the members of Parliament may vote against the referendum postulated by the sovereign.

Despite several citizens' proposals for a national referendum (state territorial division, forest privatization and reprivatization, public property privatization, land sales to foreigners, structure of the parliament, reducing the MPs number, single-member constituencies), there was not a single referendum ordered by the popular initiative.

\section{Unsuccessful proposals to hold a referendum}

Since 1989, a few dozen proposals have been submitted to organize a national referendum, with only three of them being held. Other initiatives were not either considered or accepted by a parliamentary vote. There were the matters being proposed as the subjects of referendum several times. Those were the matters related to the conditions of permissibility of abortion, related to the structure of the Polish Parliament, privatization and reprivatization of public property in Poland, affranchisement of citizens, education fees. In 2007 Prime Minister, Jarosław Kaczyński, proposed a referendum related to tax increasing and privatization of health care.

Polskiej, 2014, p. 124, available at: file://C:/Users/X/Downloads/09-ECKHARDT.pdf, access: 12 IX 2016. 
There were several attempts to make the subject of permissibility of abortion regulated through referendum. The proposal was submitted by the SLD (Democratic Left Alliance), PSL (Polish People's Party), UD (Democratic Union) and UP (Labor Union) MPs. The following four questions were formulated:

- Are you in favor of legal permissibility of abortion in the case woman's life or health are endangered?

- Are you in favor of legal permissibility of abortion in the case prenatal examination indicates heavy, irreversible damage of the embryo or incurable illness threatening the life?

- Are you in favor of legal permissibility of abortion in the case there is justified suspicion, confirmed by a prosecutor, that the pregnancy is a result of an illegal act (rape, incest) ?

- Are you in favor of legal permissibility of abortion on economic or social ground in the case a pregnant woman is in a difficult financial or family situation?

This initiative was rejected by the Sejm during the first reading and so was another initiative concerning this issue. The opponents of abortion referendum insisted that moral issues must not be settled by referendum. Those in favor of referendum, on the other hand, argued that the issue concerned rather legal than moral aspect. The government, obviously, regarded the society as not mature enough to make decisions concerning major social issues. Not accepting the possibility to hold a referendum could be regarded as certain narrowing national sovereignty ${ }^{29}$. Eventually, issues related to abortion permissibility were regulated by the representatives, with the sovereign being unable to take a stand in this matter.

In 1998, PSL (Polish People's Party) deputes came up with a proposal to hold a referendum on the territorial division of Poland. They insisted that the proposal to reduce the number of 49 voivodeships and replace them with 12 big ones would meet a significant social discontent. Thus, it was fully justified and rightful to refer to public opinion in this important matter, both for the state and its citizens. Most deputes did not approve of this proposal and the reform of the administrative division of the state was established without referring to public opinion $^{30}$.

29 A. Malinowski, Spoleczne uwarunkowania referendum, [in:] Referendum w Polsce $i w$ Europie Wschodniej, eds. M.T. Staszewski, D. Waniek, Instytut Studiów Politycznych PAN, Warszawa 1996, p. 113.

30 M. Rachwał, Demokracja bezpośrednia w procesie kształtowania się społeczeństwa obywatelskiego w Polsce, Wydawnictwo Sejmowe, Warszawa 2010, p. 199. 
At the turn of 1989/1990, ecologists in Poland protested against constructing a nuclear power plant in Żarnowiec and demanded to hold a referendum on this matter. In January 1990, a cross-party draft resolution concerning a national vote on nuclear power in Poland was submitted. As a result of local community's protests, the government withdrew from that investment, and the resolution was pointless.

While preparing the new Constitution (that came into force in 1997), Ryszard Bugaj (Labor Union Deputy) proposed referring to a referendum concerning the constitution draft. The necessity to hold a referendum on the Constitution was a result of significant differences in draft constitutions. The draft resolution of National Assembly provided that the citizens would take a stance on such issues as: structure of the parliament (unicameral or bicameral), gratuitous public education, the principle of ideological and religious neutrality of the state, public administration institutions, funding the system of health care, local government $^{31}$. Despite large public support for the referendum concerning these issues, the majority of the National Assembly did not support the initiative to hold the constitutional referendum ${ }^{32}$.

Another proposal to hold referendum concerned the ratification of Protocol No. 6 to the Convention for the Protection of Human Rights and Fundamental Freedoms. This Protocol, signed in Strasbourg in 1983, concerned the abolition of death penalty. Those being in favor of referendum did not want this document to be ratified. They took a stance that Poland should not deprive itself from the possibility to restore death penalty in the situation of increasing crime.

It is worth underlining that one of all proposals resulted in calling a Polish European Union membership referendum. There were the attempts to hold referendum on such issues as sale of land to foreigners and Polish forces in Iraq. The Polish Ombudsman made a plea to the Prime Minister to hold a referendum on the Treaty of Lisbon ratification ${ }^{33}$.

\section{Conclusions}

Since 1989 there have been five national referenda in Poland, only two of them resulted in binding decisions. There was only one referendum in which

31 M. Jabłoński, Referendum ogólnokrajowe w polskim prawie konstytucyjnym, Wydawnictwo Uniwersytetu Wrocławskiego, Wrocław 2001, p. 139.

32 R. Chruściak, W. Osiatyński, Tworzenie konstytucji w latach 1989-1997, Instytut Spraw Publicznych, Warszawa 2001, p. 285.

33 M. Rachwał, op. cit., p. 202. 
the turnout was higher than 50\% (2003). What is more, all these referenda were initiated by the representatives, not the sovereign. Therefore, the deputes decide if the sovereign implies making a decision. Nation-wide referendums in Poland are not frequent events, and it is probably a sign of unimportance of this kind of institution in Polish political system. Moreover, government's unwillingness to hold referendum on controversial public matters (e.g. permissibility of abortion) and the significant matters related to political system (structure of the Parliament) proves government's reluctance to share its decision-making competence with the sovereign. This unwillingness to refer to public opinion in controversial social and moral issues is related to a negative position expressed by the Episcopate of Catholic Church towards holding referendum on the permissibility of abortion.

It is significant that the 1995 popular initiative on the proposals to hold national referendum was constructed specifically. Here, the final decision lies in deputes hands. It means that referendum will be called in situations when it is favorable to the deputes. Referendum experience in Poland fits the thesis formulated by Gordon Smith on "controlled referendum" ${ }^{34}$. It holds three characteristics: (1) the governments decide to hold a referendum, (2) they decide when it will be held, (3) they decide what questions will be asked.

Summing up, the significance of this direct democracy institution in Poland is not serious, mainly due to the lack of an obligatory referendum, not binding character of existing forms of popular initiative and the lack of people's veto. However, it should be stressed, that no-one in Poland expects the increasing number of forms of direct democracy. Poland the same as the rest part of this region in Europe, did not have either the patterns of direct democracy, or previous experiences in it. The Poles believe in representative democracy. On the other hand, in comparison with other countries in this region, Poland seems to be almost a leader in conducting referendum.

\section{Bibliography}

- Châtelot Ch., La Pologne, le plus grand des pays candidats, dit „oui” à l'Europe, “Le Monde", 10 iunie 2003, anul. 59, nr. 18154.

- Chruściak R., Osiatyński W., Tworzenie konstytucji w latach 1989-1997, Instytut Spraw Publicznych, Warszawa 2001.

34 G. Smith, The Functional Properties of the Referendum, "European Journal of Political Research", 1976, vol. 4, no. 1, p. 6. 
- Eckhardt K., Instytucja obywatelskiej inicjatywy ustawodawczej w Rzeczypospolitej Polskiej. 2014, Available at: file://C:/Users/X/Downloads/09-ECKHARDT.pdf.

- Gebethner S., Poland, [in:] Direct Democracy. The Eastern and Central European Experience, eds. A. Auer, M. Bützer, Ashgate Publishing House, Aldershot, Burlington USA, Singapore, Sydney 2001.

- Hartliński M., The 2015 Referendum in Poland, "East European Quarterly", 2015, vol. 43, no. 2-3.

- Jabłoński M., Referendum ogólnokrajowe w polskim prawie konstytucyjnym, Wydawnictwo Uniwersytetu Wrocławskiego, Wrocław 2001.

- Jabłoński M., Obywatelskie prawo inicjatywy ustawodawczej, [in:] Prawa i wolności obywatelskie w Konstytucji RP, eds. B. Banaszak, A. Preisner, Wydawnicwto C.H. Beck, Warszawa 2002.

- Jak przyciagnąć do urn?, "Gazeta Wyborcza”, 11 VI 2003, http://www.archiwum. wyborcza.pl.

- Jahn D., Storsved A.S., Legitimacy through Referendum? The Nearly Successful Domino-Strategy of the EU-Referendums in Austria, Finland, Sweden and Norway, "West European Politics", 1995, vol. 18, no. 4.

- Jaskiernia J., Ustrojowe dylematy referendum akcesyjnego w Polsce, [in:] Wymiar społeczny członkostwa Polski w Unii Europejskiej, eds. T. Mołdawa, K.A. Wojtaszczyk, A. Szymański, Fundacja "Politeja”, Warszawa 2003.

- Kilias J., Symbole narodowe i problemy narodowościowe w polityce polskiej, [in:] Demokracja polska 1989-2003, eds. J.J. Wiatr, J. Raciborski, J. Bartkowski, B. FrątczakRudnicka, J. Kilias, Wydawnictwo Naukowe Scholar, Warszawa 2003.

- Król M., Democracy in Poland, [in:] Democratization in Central and Eastern Europe, eds. M. Kaldor, I. Vejvoda, Pinter, London-New York 1999.

- Kużelewska E., Bartnicki A.R., Referendum in Poland and Russia. Comparative analysis attempt, "The International Affairs Review”, 2008, no. 1, 2 (157, 158).

- Malinowski A., Społeczne uwarunkowania referendum, [in:] Referendum w Polsce $i$ w Europie Wschodniej, eds. M.T. Staszewski, D. Waniek, Instytut Studiów Politycznych PAN, Warszawa 1996.

- Marczewska-Rytko M., Direct democracy at the national level in Poland. The case of referendum, "Annales Universitatis Mariae Curie-Skłodowska", 2013, Sectio K, vol. XX, 1.

- Marxer W., Pállinger Z.T., System context and system effects of direct democracy direct democracy in Liechtenstein and Switzerland compared, [in:] Direct Democracy in Europe. Developments and Prospects, eds. Z.T. Pállinger, B. Kaufmann, W. Marxer, T. Schiller, Springer, Wiesbaden 2007.

- Pettersen P.A., Jenssen A.T., Listhaug O., The 1994 Referendum in Norway: Continuity and Change, "Scandinavian Political Studies", 1996, vol. 19, no. 3.

- Piasecki A.K., Demokracja bezpośrednia w Polsce po 1989 roku, "Przegląd Sejmowy”, 2006, no. 1(72).

- Prokop K., Institutions of Direct Democracy in the Republic of Poland, [in:] Proceedings of the 52nd International Scientific Conference of Daugavpils University, ed. I. Zugicka, University of Daugavpils, Daugavpils 2011.

- Puchalska B., Limits to Democratic Constitutionalism in Central and Eastern Europe, Routledge, Routledge, Farnham 2011 
- Rachwał M., Demokracja bezpośrednia w procesie kształtowania się społeczeństwa obywatelskiego w Polsce, Wydawnictwo Sejmowe, Warszawa 2010.

- Reilly S., Design, Meaning and Choice in Direct Democracy. The Influences of Petitioners and Voters, Ashgate Publishing Limited, Farnham 2010.

- Rytel-Warzocha A., Referendum ogólnokrajowe w państwach Europy Środkowo-Wschodniej, Wydawnictwo Sejmowe, Warszawa 2011.

- Smith G., The Functional Properties of the Referendum, "European Journal of Political Research", 1976, vol. 4, no. 1.

- Solecka I., Obywatele przerośli polityków, "Rzeczpospolita”, 10 VI 2003, http://archiwum.rp.pl.

- Szymański A., Frekwencja w polskim referendum akcesyjnym, [in:] Wymiar społeczny członkostwa Polski w Unii Europejskiej, eds. T. Mołdawa, K.A. Wojtaszczyk, A. Szymański, Fundacja "Politeja”, Fundacja "Politeja”, Warszawa 2003.

- Tucker J.A., Pacek A.C., Berinsky A.J., Transitional Winners and Losers: Attitudes towards EU Membership in Post-Communist Countries, "American Journal of Political Science", 2002, vol. 46, no. 3.

- Waele J-M. de, From membership referendums to European elections, [in:] European Union accession referendums, ed. J.-M. de Waele, Editions de l'Université de Bruxelles, Brussels 2005.

- Zieliński E., Referendum w Polsce, [in:] Referendum w państwach Europy, eds. E. Zieliński, I. Bokszczanin, J. Zieliński, Fundacja Europea, Oficyna Wydawnicza Aspra, Warszawa 2003.

- Referendum Act of 14 March 2003, http://isap.sejm.gov.pl (Dz. U. z 2003 r. Nr 57, poz. 507, Nr 85, poz. 782, z 2007 r. Nr 112, poz. 766, z 2009 r. Nr 68, poz. 573, Nr 202, poz. 1547, z 2011 r. Nr 21, poz. 113, Nr 106, poz. 622, Nr 147, poz. 881).

Summary: The aim of this paper is to analyse the role of direct democracy in decision-making process in Poland. The paper discusses a referendum and a popular initiative as the most often forms of expressing will by the nation. The paper examines the use of referendum and its frequency, describes which problems were to be solved in the referendum and what are the matters that are related to the projects submitted under the popular initiative. It also mentions the unsuccessful proposal to hold a referendum.

Keywords: referendum, popular initiative, direct democracy, Poland

\section{Czy Polacy wpływają na proces podejmowania decyzji przy zastosowaniu instrumentów demokracji bezpośredniej?}

Streszczenie: Celem artykułu jest analiza roli demokracji bezpośredniej w Polsce i jej wpływu na proces podejmowania decyzji politycznych. Przedmiotem rozważań jest instytucja referendum i inicjatywa ludowa jako bezpośrednia forma wyrażania woli przez naród. W artykule omawia się przedmiot głosowania w referendum, kwestie leżące u podstaw uruchomienia inicjatywy ludowej, jak również nieudane inicjatywy w zakresie przeprowadzenia referendum.

Słowa kluczowe: referendum, inicjatywa ludowa, demokracja bezpośrednia, Polska 